\title{
Villiperunan stressigeeni perunan kylmänkestävyys- ja varastointiominaisuuksien muokkaajana
}

\author{
Mervi M. Seppänen ${ }^{1)}$ ja Anne Mäittälä ${ }^{1)}$ \\ ${ }^{1)}$ Soveltavan biologian laitos, PL 27, 00014 Helsingin yliopisto, mervi.seppanen@helsinki.fi \\ anne.maittala@helsinki.fi
}

Peruna (Solanum tuberosum L.) on tunnetusti herkkä abioottisille stresseille kuten alhaiselle lämpötilalle. Sillä ei ole myöskään perinnöllistä kykyä kylmäkaraistua eli lisätä kylmänkestävyyttään altistuessaan alhaisille ei-jäädyttäville lämpötiloille. Perunan yhteyttämiskoneisto kärsii kylmävioituksista jo muutamassa pakkasasteessa. Myös perunan mukuloissa vanhenemisreaktiot sekä ei-toivottu tärkkelyksen hajoaminen nopeutuvat niiden altistuttua alhaisille lämpötiloille.

Tässä tutkimuksessa selvitettiin mahdollisuuksia parantaa perunan kylmänkestävyyttä ylituottamalla viljeltävässä perunassa kylmäkestävältä villiperunalta (S. commersonii Dun.) peräisin olevaa kylmäohjailtua stressigeeniä, glutationi S-transferaasia (GST; ScGstF1). Glutationi S-transferaasit ovat entsyymejä, jotka poistavat kasvisoluista haitallisia molekyylejä ja jotka voivat siten lieventää erilaisten stressien seurauksena syntynyttä aineenvaihdunnan epätasapainoa ja nopeuttaa stressistä palautumista. Siirtogeenin vaikutusta perunan kylmänkestävyyteen tutkittiin vertailemalla transformaatiokontrollin, viiden siirtogeeniä ylituottavan sense-linjan (S) ja kahden siirtogeeniä alituottavan antisense-linjan (AS) fotosynteesin kylmänkestävyyttä sekä siirtogeenin ilmenemisen vaikutusta siemenperunan elinvoimaan ja sadon määrään. Fotosynteesin kylmänkestävyyttä ja palautumista stressistä tutkittiin mittaamalla klorofyllifluoresenssin alenemista ( $\mathrm{FvFm}$ aleneminen, \%), klorofyllin hajoamista (klorofyllin määrää, $\left.\mathrm{ug} / \mathrm{cm}^{3}\right)$ sekä solukalvojen hapettumistuotteiden, malondialdehydin määrää (MDA, nmol/g). Siemenperunan elinvoimaa arvioitiin laskemalla siirtogeenisten siemenperunoiden itujen ja muodostuneen kasvuston varsien lukumäärä sekä mittaamalla sadon määrää.

Siirtogeeniä ylituottavissa kasveissa (S) GST-entsyymin aktiivisuus oli kohonnut verrattuna kontrollitai siirtogeeniä alituottaviin kasveihin. Stressigeeniä ylituottavissa kasveissa (S) klorofyllin määrä pysyi kontrollikasveja korkeampana stressin aikana ja sen jälkeen. Näissä kasveissa solukalvojen hajoaminen kylmästressin aikana oli myös vähäisempää mikä näkyi alhaisempana solukalvojen hajoamistuotteiden kertymisenä. Merkittäviä muutoksia fotosynteesin alenemisessa ei sen sijaan vielä havaittu lyhyen stressikäsittelyn aikana. Siirtogeenin ilmeneminen vaikutti myös perunan mukulan ominaisuuksiin. Etenkin verrattaessa siirtogeenisiä perunoita, joissa oli joko yli- tai alituotettu glutationi S-transferaasia (S, AS), eroja havaittiin siemenperunasta muodostuneiden itujen ja versojen määrässä sekä lopullisessa perunasadossa. Siirtogeeniä ylituottavissa kasveissa (S) itujen ja versojen lukumäärä oli alhaisempi ja korjatun sadon määrä yksittäisissä tutkituissa linjoissa kontrollikasveja korkeampi. Itujen ja versojen vähäisempi määrä voidaan tulkita siirtogeeniä ylituottavien (S) mukuloiden säilymisenä nuorempana varastoinnin aikana. Tulokset sekä perunakasvuston kylmänkestävyydestä että siemenperunan elinvoiman säilyvyydestä varastoinnin aikana viittaavat siihen, että stressigeeni ylituotto vaikuttaa positiivisesti näihin ominaisuuksiin. Yksittäisen stressigeenin ylituoton vaikutus on pieni lyhyen stressin, kuten tässä tutkimuksessa kasvuston kylmäaltistuksen yhteydessä, mutta vaikutuksen merkitys lisääntyy stressijakson pidentyessä. Tämä havaittiin tutkittaessa siirtogeenin vaikutusta pitkän, alhaisessa lämpötilassa tapahtuvan varastoinnin jälkeen. Sekä kylmästressi että varastointi alhaisessa lämpötilassa kuluttavat kasvin puolustuskapasiteettia. Kun puolustuskapasiteetti ylittyy ja haitallisia molekyylejä kertyy kasvisoluun, seuraa vaurioita, jotka voidaan havaita esimerkiksi klorofyllin hajoamisena lehdissä tai nopeutuneena mukuloiden vanhenemisena varastossa. Tulokset viittaavat siihen, että puolustuskapasiteetin parantaminen GST entsyymin aktiivisuutta lisäämällä voi olla hyödyllistä perunalle etenkin stressin pitkittyessä.

Avainsanat: glutathioni S-transferaasi, kylmänkestävyys, varastointi 


\section{Johdanto}

Viljeltävä peruna, S. tuberosum L., on kylmänherkkä kasvi, jonka kasvusto kestää noin $-3^{\circ} \mathrm{C}$ lämpötiloja eikä lajikkeiden välillä esiinny kestävyyseroja (Seppänen ym. 2001). Perunan villeistä sukulaisista $S$. commersoniilla on parempi kylmänkestävyys ja lisäksi laji pystyy lisäämään kylmänkestävyyttään karaistumalla. S. tuberosumin ja $S$. commersoniin välinen somaattinen hybridi ja siitä tuotetut jälkeläiset perivät osittain $S$. commersoniin paremman kylmänkestävyyden ja kyvyn kylmäkaraistua (Seppänen ym. 1998). Tutkittaessa hybridin jälkeläistöä havaittiin, että linjojen parantunutta kylmänkestävyyttä selitti niiden korkeampi antioksidatiivinen puolustuskapasiteetti ja kylmäohjailtujen geenien aktivoituminen karaistumisen aikana (Seppänen ym. 1998, Seppänen \& Fagerstedt 2000, Seppänen \& Coleman 2003). Perunan yhteyttämistehokkuus alenee herkästi jo ennen kuin merkkejä kylmävaurioista esiintyy lehdillä. Villiperunoilla korkeamman antioksidatiivisen puolustuskapasiteetin onkin havaittu suojaavan erityisesti yhteyttämiskoneistoa kylmän aiheuttamilta vaurioilta (Seppänen ym. 1998, Seppänen \& Coleman 2003).

Villiperuna-aineistosta saatujen tulosten perusteella lähdettiin perunan kylmänkestävyyttä parantamaan ylituottamalla viljeltävässä perunassa $S$. commersoniilta peräisin olevaa stressigeeniä, glutationi Stransferaasia (GST) (Seppänen ym. 2000). Glutathioni S-transferaasit (GST) ovat laaja perhe entsyymejä, jotka poistavat soluista niihin kertyneitä haitallisia molekyylejä (Edwards ym. 2000). Osalla GST entsyymeistä on lisäksi peroksidaasi-aktiivisuutta ja ne osallistuvat aktiivisesti solukalvojen hajoamisessa syntyneiden reaktiivisten molekyylien sieppaukseen ja hillitsevät siten solukalvojen hajoamisen ketjureaktiota (Roxas ym. 2000).

Myös varastoinnin aikana perunan mukulaan voi kertyä haitallisia yhdisteitä kuten solukalvojen rasvahappojen hajoamistuotteita, joka voi johtaa nopeutuneeseen vanhenemiseen ja laatuominaisuuksien alenemiseen (Kumar \& Knowles 1993, 1996). Tärkkelysjyvästen ympärillä olevien solukalvojen rikkoutumisen jälkeen varastointilämpötilassa aktivoituneet amylaasi-entsyymit pääsevät esteettömästi hajottamaan tärkkelystä. Solukalvojen hajoaminen siten nopeuttaa mukulan laadun heikkenemistä. Eräiden glutathioni S-transferaasien tiedetään sitovan solukalvojen hajoamisessa syntyviä lipidiperoksi-radikaaleja ja hidastavan solukalvojen hapettumiseen johtavaa ketjureaktiota (Edwards ym. 2000, Roxas ym. 2000).

Tässä tutkimuksessa selvitettiin voidaanko perunan kasvuston kylmänkestävyyttä sekä mukuloiden varastointikestävyyttä parantaa ylituottamalla perunassa villiperunalta peräisin olevaa stressigeeniä ja miten stressigeenin ilmeneminen vaikuttaa siemenperunan ominaisuuksiin sekä sadon määrään.

\section{Aineisto ja menetelmät}

Villiperunan S. commersoniin, cDNA kirjastosta eristetty kylmäindusoituva glutationi S-transferaasi (ScGstF1) geeni (GenBank AF002692) kloonattiin pTT294 transformaatiovektoriin sense (S) ja antisense (AS) orientaatioon konstitutiivisen $35 \mathrm{~S}$ promoottorin ohjattavaksi ja transformoitiin S. tuberosum (cv.Pito). Transformaatiokontrollina käytettiin tyhjällä pHTT294 transformoitua linjaa (pHTT294). Kasvien siirtogeenisyys varmistettiin PCR:n, Northern-hybridisaation sekä GST entsyymiaktiivisuuden perusteella.

Siirtogeenin vaikutusta perunan kylmänkestävyyteen tutkittiin vertailemalla transformaatiokontrollia (pHTT294), viittä sense-linjaa (S) ja kahta antisense-linjaa (AS) keskenään. Kasvihuoneella 4-6 viikkoa kasvaneista linjoista kerättiin lehtikiekkonäytteitä, jotka altistettiin alhaiselle lämpötilalle $\left(-1^{\circ} \mathrm{C}\right)$ ja jatkuvalle valolle (700 umol m $\left.\mathrm{m}^{-2} \mathrm{~s}^{-1}\right) 40$ tunnin ajan, jonka jälkeen palautumista seurattiin 20 tunnin kuluttua stressin loppumisesta. Mainittuina ajankohtina mitattiin klorofyllifluoresenssin alenemista (FvFm aleneminen, \%), klorofyllin hajoamista (klorofyllin määrää, ug/ $\mathrm{cm}^{3}$ ) sekä solukalvojen hapettumistuotteiden, malondialdehydin määrää (MDA, nmol/g).

Siirtogeenin vaikutusta siemenperunan elinvoiman ja sadon määrään tutkittiin kasvihuonekokeissa. Siemenperunana käytettyjen mukuloiden itujen sekä kasvuston varsien lukumäärä laskettiin. Kasvuston vanhenemisesta tehtiin havaintoja ja kasvikohtainen satomäärä punnittiin.

\section{Tulokset}

Siirtogeenisyys todennettiin PCR:n ja Northern hybridisaation lisäksi mittaamalla siirtogeenisten linjojen glutationi S-transferaasi entsyymin kokonaisaktiivisuutta. Sense-linjoissa (S), joissa siirtogeeniä oli ylituotettu, mitattiin tilastollisesti merkitsevästi korkeampi ( $\mathrm{p}<0,05)$ GST aktiivisuus, 5,56 (absorbanssin muutos $\mathrm{A}_{340} * 10^{-3} \mathrm{~min} \mu \mathrm{g}^{-1}$ protein $\left.^{-1}\right)$. Sen sijaan GST kokonaisaktiivisuus ei eronnut kontrolli ja 
alituottavien linjojen välillä, joissa aktiivisuus oli vastaavasti 4,72 ja 4,77 (absorbanssin muutos $\mathrm{A}_{340} * 10^{-3}$ $\left.\min \mu \mathrm{g}^{-1} \operatorname{protein}^{-1}\right)$.

Siirtogeenin ylituotto vaikutti positiivisesti perunan palautumiseen kylmästressistä etenkin kun palautumista mitattiin klorofyllin määrän muutoksena (Taulukko 1). Myös yhteyttämiskyvyn alenemisesta saatiin samansuuntaisia viitteitä, jossa havaitut erot eivät tosin olleet tilastollisesti merkittäviä kuten klorofyllin määrässä havaitut erot. Myös solukalvojen hajoamistuotteiden määrä oli siirtogeenisissä kasveissa alhaisempi kontrollikasveihin verrattuna. Kaikki kylmävaurioiden määrästä kertovat mitatut muuttujat; fotosynteesikyvyn aleneminen, klorofyllin määrä ja solukalvon hajoamistuotteiden kertyminen viittaavat samansuuntaisesti siihen, että siirtogeeniset perunat hyötyivät etenkin stressin palautumisvaiheessa korkeammasta glutathioni S-transferaasi-entsyymin aktiivisuudesta. Yleisemmin kylmästressin aiheuttamat vauriot havaitaankin juuri palautumisvaiheessa; stressin aikana etenkin energia-aineenvaihdunta joutuu epätasapainoon aiheuttaen reaktiivisten hapen radikaalien kertymisen kasvisoluun. Näitä hapen radikaaleja poistetaan antioksidanttien avulla ja siten stressin palautumisvaiheessa antioksidanttien määrä on usein alimmillaan.

Taulukko 1. Siirtogeenisten perunoiden fotosynteesin palautuminen kylmästressistä. Stressigeeniä joko ali- (AS) tai ylituotettiin (S) siirtogeenisissä kasveissa ja stressigeenin aikaansaamia muutoksia verrattiin transformaatiokontrolliin (pHTT). Siirtogeenisten kasvien tulokset on esitetty kahden AS-linjan ja viiden S-linjan keskiarvoina. Keskiarvo. $\mathrm{n}=5$, $\mathrm{p}<0,05$.

\begin{tabular}{llccc} 
& & $\mathbf{0 ~ t}$ & $\mathbf{4 0 ~ t}$ & Palautuminen, 20 t \\
\hline Fv/Fm aleneminen, \% & pHTT & 0 & $39,7 \mathrm{~b}$ & $5,0 \mathrm{a}$ \\
& AS & 0 & $50,5 \mathrm{a}$ & $5,1 \mathrm{a}$ \\
& S & 0 & $37,2 \mathrm{~b}$ & $6,0 \mathrm{a}$ \\
\cline { 2 - 5 } Klorofyllin määrä, & pHTT & $50,8 \mathrm{~b}$ & $49,4 \mathrm{a}$ & $39,1 \mathrm{~b}$ \\
ug/cm & AS & $45,6 \mathrm{c}$ & $43,5 \mathrm{~b}$ & $39,1 \mathrm{~b}$ \\
& S & $58,7 \mathrm{a}$ & $53,3 \mathrm{a}$ & $45,0 \mathrm{a}$ \\
\hline MDA, nmol/g & pHTT & $28,8 \mathrm{a}$ & $35,9 \mathrm{a}$ & $39,6 \mathrm{a}$ \\
& AS & $31,5 \mathrm{a}$ & $23,3 \mathrm{~b}$ & $31,8 \mathrm{~b}$ \\
& S & $28,6 \mathrm{a}$ & $24,4 \mathrm{~b}$ & $34,8 \mathrm{ab}$ \\
\hline
\end{tabular}

Perunoissa, joissa stressigeenin määrää oli alennettu (AS), itämislepo oli lyhyempi ja siemenperunaan oli ehtinyt muodostua runsaasti ituja ennen istutusta (Taulukko 2). Runsas itujen lukumäärä näkyi myös suurempana varsien lukumääränä muodostuneessa kasvustossa. Kontrollin ja stressigeeniä ylituottavien perunoiden siemenperunoiden itujen tai kasvuston varsilukumäärissä ei havaittu eroja.

Taulukko 2. Siirtogeenin vaikutus siemenperunan ominaisuuksiin (itujen ja versojen $\mathrm{lkm}$ ) sekä sadon määrään (g/kasvi). Stressigeeniä joko ali(AS) tai ylituotettiin (S) siirtogeenisissä perunoissa ja stressigeenin aikaansaamia muutoksia verrattiin transformaatiokontrolliin (pHTT). Keskiarvo (n=5), $\mathrm{p}<0,05$.

\begin{tabular}{clcc} 
& Itujen lkm & Versojen $\mathbf{l k m}$ & Sato $(\mathbf{g})$ \\
\hline pHTT & $9,2 \mathrm{ab}$ & $9,2 \mathrm{ab}$ & $306,1 \mathrm{a}$ \\
AS1 & $11,8 \mathrm{a}$ & $11,0 \mathrm{a}$ & $290,8 \mathrm{a}$ \\
AS2 & $17,8 \mathrm{a}$ & $13,8 \mathrm{a}$ & $175,8 \mathrm{a}$ \\
S1 & $9,6 \mathrm{~b}$ & $6,0 \mathrm{bc}$ & $483,5 \mathrm{a}$ \\
S2 & $7,4 \mathrm{ab}$ & $5,0 \mathrm{c}$ & $304,8 \mathrm{a}$ \\
S3 & $8,8 \mathrm{ab}$ & $5,0 \mathrm{c}$ & $497,3 \mathrm{a}$ \\
S4 & $8,8 \mathrm{ab}$ & $6,6 \mathrm{bc}$ & $446,8 \mathrm{a}$ \\
S5 & $9,6 \mathrm{ab}$ & $6,4 \mathrm{bc}$ & $397,8 \mathrm{a}$ \\
\hline
\end{tabular}

Kontrollikasvien tai siirtogeenisten linjojen sadoissa ei mitattu tilastollisesti merkitseviä eroja, mutta joidenkin stressigeeniä ylituottavien linjojen (S1 ja S3) sato oli selkeästi kontrollikasveja korkeampi (Taulukko 2). Kasviyksilöiden sadoissa olleesta suuresta vaihtelusta johtuen tuloksiin sisältyvä hajonta on suuri. 


\section{Tulosten tarkastelu}

Abioottisen stressin seurauksena kasvin aineenvaihdunta joutuu helposti epätasapainoon ja toksisia aineenvaihduntatuotteita alkaa kertyä. Kun puskurikapasiteetti ylittyy, alkaa muodostua vaurioita, jotka ensimmäisenä havaitaan yhteyttämiskyvyn alenemisena ja solukalvojen osittaisena rikkoutumisena. Jos stressiolot jatkuvat tai stressi toistuu useita kertoja, kasvin puolustuskapasiteetti ylittyy, palautumattomia vaurioita muodostuu ja kasvi kuolee.

Tällaisia aineenvaihdunnan epätasapainon seurauksena muodostuneita stressioireita on onnistuttu lieventämän ylituottamalla kylmänherkissä kasveissa antioksidantteja (Sung ym. 2003) tai entsyymejä kuten glutathioni S-transferaasi (Roxas ym. 2000), joka detoksifioi myrkyllisiä yhdisteitä kuljettamalla ne vakuoliin. Perunalla stressinkestävyyden parantaminen on erityisen haasteellista, sillä perunan mukulat varastoidaan pitkään, ne ovat varastoinnin aikana metabolisesti hyvin aktiivisia ja siten myös siirtogeeni, geenin ilmenemistä ohjailevasta säätelyalueesta riippuen, voi olla aktiivinen varastoinnin aikana.

Tässä tutkimuksessa perunan kylmänkestävyyttä, lähinnä ei-jäädyttävien, alhaisten lämpötilojen kestävyyttä pyrittiin parantamaan ylituottamalla viljeltävässä perunassa villiperunalta peräisin olevaa kylmäohjailtua stressigeeniä, glutathioni S-transferaasia. Stressigeenin ylituoton hyöty perunan kylmänkestävyydelle pystyttiin havaitsemaan hieman parantuneena palautumiskykynä kylmästressistä. Luonnossa viileät ajanjaksot, jotka vaikuttavat haitallisesti perunan energia-aineenvaihduntaan, voivat kestää pitkiäkin ajanjaksoja tai kylmästressi toistuu yö toisensa jälkeen. Tällaisissa tilanteissa parantunut palautumiskyky voi estää letaalien vaurioiden kehittymisen perunoissa.

Siirtogeenin ilmeneminen vaikutti myös perunan mukulan ominaisuuksiin. Varastoinnin aikana perunan mukula hengittää ja kuluttaa energia- ja antioksidatiivisia varastojaan. Mukulan vanheneminen näkyy mm. apikaalimeristeemin dominanssin murtumisena sekä solukalvojen hajoamisen lisääntymisenä. Periaatteessa parempi antioksidatiivinen kapasiteetti voi viivästyttää vanhenemisen ketjureaktion etenemisnopeutta (Kumar \& Knowles 1993, 1996). Glutationi S-transferaasien geeniperhe on suuri ja osalla geeniperheen jäsenistä on myös antioksidatiivisia ominaisuuksia, kuten glutationi peroksidaasi-aktiivisuutta. Vaikka villiperunalta siirretty glutationi S-transferaasi ei omaa peroksidaasiaktiivisuutta, havaittiin siirtogeenisissä perunan mukuloissa eroja niiden vanhenemisnopeudessa. Etenkin verrattaessa siirtogeenisiä perunoita, joissa oli joko yli- tai alituotettu glutationi S-transferaasia, eroja havaittiin siemenperunasta muodostuneiden itujen ja versojen määrässä sekä lopullisessa perunasadossa. Tulosten perusteella voidaan todeta, että pienetkin muutokset siirtogeenitekniikan avulla voivat vaikuttaa merkittävästi siemenperunan ominaisuuksiin.

\section{Johtopäätökset}

Villiperunalta peräisin olevan stressigeenin yli- ja alituottaminen siirtogeenisissä perunoissa vaikutti niin perunakasvustoon kuin siemenperunan ominaisuuksiin. Positiivisia vaikutuksia havaittiin perunan palautumisessa kylmästressistä sekä siemenperunoiden vanhenemisessa ja satopotentiaalin säilymisessä. Tutkimukset suoritettiin kontrolloiduissa oloissa kasvihuoneessa ja kasvatuskaapissa. Se, miten siirtogeenin vaikutukset näkyvät pelto-oloissa, joissa stressiolot kestävät usein pidempään ja stressin aste vaihtelee kasvukauden aikana, jää nähtäväksi. Teoriassa voi siirtogeenisten kasvien tehostunut haitallisten molekyylien poisto olla hyödyllistä mitä moninaisimmissa stressioloissa.

\section{Kirjallisuus}

Edwards R., Dixon, D.P. \& Walbot, V. 2000. Plant glutathione S-transferases: enzymes with multiple functions in sickness and in health. Trends in Plant Sci. 5:193-196.

Kumar, M.G.N. \& Knowles R.N. 1996. Oxidative stress results in increased sinks for metabolic energy during aging and sprouting of potato seed-tubers. Canadian J. of Bot. 71:541-550.

Kumar, M.G.N. \& Knowles R.N. 1993. Changes in lipid peroxidation and lipolytic and free-radical scavenging enzyme activities during aging and sprouting of potato (Solanum tuberosum) seed-tubers. Plant Physiol. 102:115-124.

Roxas, V.P., Lodhi, S., Garrett, D.K., Mahan, J.R. \& Allen, R.D. 2000. Stress tolerance in transgenic tobacco seedlings that overexpress glutathione S-transferase/glutathione peroxidse. Plant Cell Physiol. 41:1229-234. 
Seppänen, M. M, Cardi, T., Borg Hyökki, M., Pehu, E. 2000. Characterization and expression of cold-induced glutathione S-transferase in freezing tolerant Solanum commersonii, sensitive S. tuberosum and their interspecific somatic hybrids. Plant Sci. 153(2)125-133.

Seppänen, M.M.\& Coleman, G. 2003. Characterization of genotypic variation in stress gene expression and photosynthetic parameters in potato. Plant, Cell and Environment 26, 401-410.

Seppänen, M.M, \& Fagerstedt, K. 2000. Superoxide dismutase activity in response to cold acclimation in potato. Physiol. Plant, 108:279-285.

Seppänen, M.M., Nissilä, O., Perälä, S. 2001. Tolerance to freezing and low temperature photoinhibition in cultivated potato and potato hybrids. Food and Agric. Sci of Finland 10:153-163.

Seppänen, M., Majaharju, M., Somersalo, S. \& Pehu, E. 1998. Freezing tolerance and cold acclimation of potato. Paraquat tolerance is related to acclimation process but not a good indicator of freezing tolerance. Physiol. Plantarum 102:454-460. 410.

Sung, D-Y., Kaplan, F., Lee, K-J. \& Guy, C.L. 2003. Acquired tolerance to temperature extremes. Trends in Plant Sci. 8:179-187. 